This PDF is a selection from an out-of-print volume from the National Bureau of Economic Research

Volume Title: Topics in Empirical International Economics: A Festschrift in Honor of Robert E. Lipsey

Volume Author/Editor: Magnus Blomstrom and Linda S. Goldberg, editors

Volume Publisher: University of Chicago Press

Volume ISBN: 0-226-06083-7

Volume URL: http://www.nber.org/books/blom01-1

Conference Date: December 3-4, 1998

Publication Date: January 2001

Chapter Title: Measuring Product-Market Integration

Chapter Author: Michael M. Knetter, Matthew J. Slaughter

Chapter URL: http://www.nber.org/chapters/c10577

Chapter pages in book: (p. 15 - 46) 


\title{
Measuring Product-Market \\ Integration
}

\author{
Michael M. Knetter and Matthew J. Slaughter
}

\subsection{Introduction}

Globalization - the integration of national economies - has become one of the most widely used buzzwords of the late twentieth century. It is frequently given credit or blame for all manner of economic outcomes. While many signs of globalization are quite obvious, it is hard to say whether market integration is more important for economic performance today than it was thirty years ago. But one thing is certain: Few people have done more to advance our understanding of the manifold dimensions of economic integration than Robert Lipsey. Lipsey and numerous coauthors have chronicled market integration in all its dimensions - the behavior of relative prices, national price levels, volume flows of traded goods, and volume flows of foreign direct investment - in as much detail as anyone (e.g., Lipsey 1963). As a result, much of what we know about the extent of international economic integration is due to him. In this paper we try to make a further contribution to that understanding, particularly in the area of the integration of markets for traded goods.

What drives globalization? In financial markets, integration has been driven by declines in both natural and political trade barriers. For example, the proliferation of computer technology has drastically cheapened trading and communication; at the same time, policy makers have elimi-

Michael M. Knetter is professor of international economics at the Tuck School of Business, Dartmouth College, and a research associate of the National Bureau of Economic Research. Matthew J. Slaughter is assistant professor of economics at Dartmouth College and a faculty research fellow of the National Bureau of Economic Research.

For helpful comments the authors especially thank Jim Harrigan; they also thank the other participants at the Festschrift conference. For excellent research assistance the authors thank Rob Simik. For financial support Slaughter thanks the Russell Sage Foundation. 
nated a wide range of restrictions on international capital flows. The results are clear in terms of both quantities and prices. In 1973 the daily turnover in worldwide foreign exchange trading averaged about $\$ 10$ billion; today this quantity has increased more than a hundredfold to well over $\$ 1$ trillion. And across many countries, covered interest parity holds much more closely today than it did twenty years ago. In light of this evidence on both quantities and prices, there is a consensus that financial markets are much more integrated today than they were twenty years ago.

Many of the same forces driving financial market integration have also been operating in goods markets, so it is tempting to conclude that product markets have integrated as well. Natural trade barriers have fallen with improvements in transportation such as supertankers and wide-body jets. On the political side, successive General Agreement on Tariffs and Trade (GATT) rounds have greatly reduced tariffs on manufactures and have expanded the scope of liberalization to many nonmanufacturing sectors as well. In addition to multilateral liberalization, many countries have also lowered barriers through regional arrangements such as the European Union (EU) and the North American Free Trade Agreement (NAFTA).

Other factors have been working against product-market integration, however. First, the many regional trading blocs that have formed in recent years can divert trade as well as create it. Second, as tariff barriers have declined, many countries have increasingly resorted to nontariff barriers (NTBs) to impede trade. Arrangements such as the Multi-Fiber Arrangement (MFA) and "voluntary" export restraints in the U.S. automobile market have proliferated. The aggressive use of antidumping laws to protect domestic industries is common in the United States and Europe. Recent complaints levied by U.S. steel makers remind us of the importance of these tools in restricting the flow of goods and distorting prices. Rough measures of the existence of NTBs, such as coverage ratios, are available, but these measures do little to gauge the extent to which NTBs actually inhibit trade. Unlike tariff rates, they do not tell us how great a wedge is created between prices of similar goods in different markets. Overall, with the decline of natural trade barriers and tariffs on the one hand and the rise of regional blocs and NTBs on the other, it is difficult to say a priori just how much more integrated product markets have become in recent years. ${ }^{1}$

In this paper we present some new price- and quantity-based measures of product-market integration. Documenting trends in market integration is interesting in itself; but it will also help us understand the link between

1. Widely available volume measures, such as trade/GDP ratios, may really reflect something about the nature of economic growth rather than the integration of product markets. Harrigan (1993) provides direct evidence on how much trade barriers reduce import volumes. Using a 1983 sample of OECD countries, he finds that tariffs and transportation costs reduce import volumes much more than NTBs do. 
countries' trade policies and their economic performance. Do countries grow faster as their product markets become more connected to those of other countries? Has product-market integration contributed to rising income inequality in countries? By studying product-market integration in multiple dimensions - across countries, industries, and time — we hope to assemble some facts on integration that will permit more powerful tests of the impact of integration on national economic performance.

This paper is organized as follows. Section 1.2 discusses the process of economic integration and its implications for economic outcomes. Section 1.3 presents our data and framework for analyzing product price evidence on integration. Section 1.4 presents our data and framework for analyzing quantity evidence on integration. Section 1.5 concludes.

\subsection{Perspectives on Economic Integration}

Before discussing the conceptual issues that underlie the measurement of product-market integration, it is worth remembering why we care about this integration in the first place. Economic integration has many consequences for the operation of a market economy. First, it can affect an economy's response to monetary and fiscal policies. In each case, tighter connections between domestic and foreign markets can reduce the potency of conventional demand stimuli. For example, increased lending by domestic banks or increased spending by domestic consumers may be directed at foreign firms. Second, greater integration can allow external factors to exert greater influence on domestic outcomes. For example, increased product-market competition from less developed countries might be contributing to the ongoing rise in the U.S. skill premium. The exact degree to which economic integration affects domestic outcomes remains open to speculation, however. In part, this is because we have only rough metrics by which to measure the extent of integration, especially in product markets. Our paper aims to provide some new measures.

Broadly speaking, there are two ways to proceed in measuring productmarket integration. One approach would be to assemble direct evidence on the magnitude of barriers between national markets. Included here would be shipping costs, tariffs, and any other barriers that make costly the international movement of goods. In general, we expect the degree of market integration to vary inversely with the magnitude of these barriers.

Available data on tariff rates and transport costs certainly confirm the view that markets have become more integrated in recent years. Figure 1.1 presents some evidence of declining U.S. barriers. Average tariff rates cover all U.S. manufacturing imports; each year's rate measures the total tariff revenue collected, divided by the value of all dutiable imports. Average transportation costs also cover all U.S. manufacturing; each year's rate measures the cost, insurance, and freight for all U.S. imports, divided by 




Fig. 1.1 Declining U.S. trade barriers

Source: Feenstra (1996).

Note: Data cover all U.S. manufacturing. Tariff rate is defined as total manufacturing duties collected divided by total manufacturing free on board (f.o.b.) imports. Transportation cost is defined as the difference between total manufacturing imports valued cost, insurance, freight (c.i.f.) and f.o.b. divided by total manufacturing f.o.b. imports.

the value (excluding the shipping costs) of all imports. These data come from Feenstra (1996). As figure 1.1 shows, average U.S. tariffs and transportation costs have generally been declining the past twenty years. This suggests that U.S. product markets have become more integrated with world markets.

These direct measures of integration are suggestive, but they face at least three important limitations. First, these ex post measures omit the cost of prohibitive barriers - that is, tariffs or transportation costs that are so high that U.S. imports are zero. Second, these tariff measures completely omit all NTBs. This matters because NTBs, both intended and unintended, are now the primary barriers between countries in many product categories. Third, even if NTB data were readily available they likely could not be easily quantified as a cost of moving goods. Details of NTBs vary so much by product that it would be hard to systematically assemble such information. On all counts, these measures may overstate the degree of product-market integration.

These limitations suggest the need for an alternative approach to measuring economic integration. This is to examine equilibrium outcomesthe prices and quantities generated in various markets - to see if they are consistent with a marked change in the magnitude of barriers separating national markets for goods. For example, price equalization for a good would suggest that trade barriers for that good had been eliminated. This is the approach we use in this paper. 
One advantage of this approach is that, relative to measuring barriers, measuring outcomes offers more hope for comparability of data across countries, product categories, and time, thanks in part to the efforts of Robert Lipsey through initiatives such as the International Comparisons Program (ICP) and the NBER World Trade Flows Database. For efforts to measure globalization across lots of dimensions, this advantage is particularly important. One disadvantage of this approach is it does not link outcomes back to barriers. Without these links one cannot rule out the possibility that changes in outcomes are caused by forces other than declining barriers, such as economic growth. Increased trade flows among a set of countries might be caused by declining trade barriers. As Helpman (1987) has shown, however, it might also be caused by convergence of country incomes - which in turn may be caused by forces such as technological convergence or factor accumulation. We acknowledge this disadvantage of outcome-based measures, yet point out that for many important issues, outcome-based integration matters regardless of the cause(s). For example, if changes in a country's relative product prices are raising domestic wage inequality, that outcome is the same for workers whether it is caused by reduced transportation costs or by growth abroad.

To date, most descriptions of product-market integration have focused on trade volumes rather than on trade prices. ${ }^{2}$ However, in standard models, trade benefits a country both by compelling its producers to reallocate resources across industries and by presenting its consumers with an improved range of options. The mechanism that generates these gains is a change in the vector of traded-goods prices facing the country. As these prices come to match those of the world, a country benefits by specializing in its comparative-advantage goods and exporting them in exchange for the rest of the world's comparative-advantage goods. The potential benefits of facing world prices are not limited to these gains from reallocating resources. At least three additional gains from facing world prices arise in some models: reduced market power for firms and thus smaller price-cost margins in the imperfect-competition models from new trade theory, higher firm productivity via reduced $\mathrm{X}$-inefficiencies, and greater capital accumulation. Thus, trade theory makes clear that an important-if not the most important-aspect of goods-market integration is facing world prices of traded goods.

While it may be true that prices carry the important economic signals associated with increased market integration, it is also true that in most cases, these signals will lead firms and consumers to make new allocation decisions. The patterns of production and consumption (and thus, of imports and exports) are almost certain to change in concert with the change

2. See, e.g., Krugman (1995) or Irwin (1996). Another popular strain of the literature on integration relies on gravity models of trade volumes. 
in prices. Therefore, it is of great interest to look at quantity data as well in assessing the changing extent of economic integration across countries.

Given our decision to measure integration with price and quantity outcomes, it is important to clarify how reductions in natural and political trade barriers change these equilibrium outcomes. To do this we outline these changes from two alternative perspectives. The first is the standard Heckscher-Ohlin (HO) model, in which the key determinant of trade is international differences in relative factor endowments. In the textbook two-good setup, we imagine that one country specializes in cars and the other in shirts, and that they trade to satisfy their preferences. When barriers fall, countries specialize more in production (production becomes more dissimilar across the countries) and trade more with each other. Our second perspective also presumes endowment differences, but here the product space actually evolves as a result of the opportunity to trade. The production of the car may become fragmented into the production of car components. The country that specializes in shirts may now make the fabric for the car seats. The country that specializes in cars may now make the machines that make shirts. We call this second model $\mathrm{HO}$ plus production fragmentation. ${ }^{3}$ Feenstra $(1998,13)$ describes this model as characterized by "the increased use of imported [intermediate] inputs, and narrowing of production activities within each country."

In both models, declining trade barriers permit production reorganization according to comparative advantage. In the standard model, there is no real distinction between "industries" and "activities." In the modified model, the distinction is quite important. Specialization occurs on the basis of comparative advantage in activities. This distinction matters because data are organized by industry, rather than activity. As a result, the normal patterns of specialization by industry, which seem natural from the perspective of the standard HO model, may not arise in the data if vertical specialization is occurring within industries according to activity. In the rest of this section we briefly discuss these differences. We start with prices.

First, consider prices charged to various destination markets by exporters in a particular source country. With integration, price dispersion across destination markets should decline over time in the standard HO world. This follows from the law of one price (LOP). As barriers preventing crosscountry arbitrage decline, a particular source country must charge increasingly uniform prices to destination markets. In the HO-fragmentation world, things are less clear because integration can change the activity composition of exports. For example, initially a country might export fully

3. What we are calling "fragmentation" has been labeled differently by various authors: "kaleidoscope comparative advantage" (Bhagwati and Dehejia 1994), "slicing the value chain" (Krugman 1995), and "delocalization" (Leamer 1998). 
assembled cars. Declining barriers might lead the country to export partially assembled cars to certain markets and fully assembled cars to other markets. If there are destination-specific differences in goods arising as a result of specialization by activity, then price dispersion across destinations need not decline. In fact, it could easily increase.

Second, consider relative price structure for producer goods within each country. With integration, the relative price structure should become more similar across countries over time in the standard HO world. Again, this follows from the LOP. But in the HO-fragmentation world, relative producer prices need not become more similar across countries. Industry-level producer prices might actually become less similar across countries as the mix of activities within each industry becomes less similar across countries, thanks to greater specialization by activity.

Third, consider relative consumer prices for final goods (across all industries) within each country. If consumers worldwide share similar tastes for consumption in terms of industries, then integration should make these relative prices more similar across countries. Note that this is true even from the HO-fragmentation perspective. Within-industry activities matter in price dispersion for intermediate goods, but not for final goods.

We now consider how integration from these two perspectives affects quantities of both trade and production. In a multilateral world, with either standard $\mathrm{HO}$ or HO-fragmentation we expect to see rising trade "incidence" in terms of the frequency of bilateral trade flows for each industry. However, in the standard $\mathrm{HO}$ world all this trade would be interindustry trade, whereas in the HO-fragmentation world much of it would be intraindustry trade of activities within industries.

Production patterns should also look different across the two perspectives. In the standard $\mathrm{HO}$ world, if countries focus production on comparative-advantage industries, then the vector of output shares should grow more dissimilar across countries over time for given factor endowments. In the HO-fragmentation world, however, the product mix might grow more similar across countries over time. Consider the example of automobile production for these two cases. With integration in the standard $\mathrm{HO}$ model, countries with a comparative advantage in automobiles would increase their automobile shares of domestic production, while countries with a comparative disadvantage would reduce their automobile shares. But in the HO-fragmentation world, most (perhaps all) countries move into some aspect of car production: Different countries focus on different activities, but many might have at least some output in the car industry. Another different feature of the HO-fragmentation world is that the share of domestic value added in industry gross output might fall across industries and countries as countries increasingly rely on imported intermediate inputs. The standard $\mathrm{HO}$ world does not carry this prediction. 
In general, the predicted effects of integration on industry-level data are less clear for the HO-fragmentation model than for the standard HO model. While this is not a new idea, it is an important empirical consideration because most readily available international data are at high enough levels of aggregation to mask particular activities. Feenstra (1998) provides rich anecdotal and systematic evidence that production fragmentation has increased in recent years.

\subsection{Evidence from Prices}

The absolute version of the LOP provides one natural benchmark for assessing the integration of markets. Presumably, globalization would reduce the magnitude of deviations from the LOP. Another benchmark might involve relative prices: Globalization should force countries to face increasingly similar relative-price vectors for traded goods. This definition might be attractive in instances in which misalignments of exchange rates might generate substantial short-run deviations from the absolute or relative LOP.

The usefulness of these benchmarks is limited by data constraints, however. There are no comprehensive data on local-currency prices of identical products across countries. Thus, any attempt to measure integration using product prices will typically require a compromise in one of the three dimensions emphasized previously: comprehensiveness, unit of measure (e.g., comparing measures such as indexes whose levels are arbitrary), or product differentiation. Although much research has tested the relative LOP (e.g., Kravis and Lipsey 1977), most of this work says nothing about the changing degree of integration. Somewhat ironically, the movement from segmented to integrated markets would appear in the data as a departure from the relative LOP (or, alternatively, as pricing-to-market). In general, it is difficult to study price convergence with indexes-which contain no information about price levels.

\subsubsection{The Behavior of Deviations from the Law of One Price}

It may seem obvious that deviations from the LOP should be decreasing as markets integrate, but it is less clear whether absolute or relative (i.e., percentage) deviations from the LOP are what matters. Therefore, it is worth considering what price dispersion actually reveals about integration.

Theoretically, price discrimination across markets arises as a result of (1) differences in demand characteristics across groups of consumers (in our case, the groups refer to countries) and (2) the ability of firms to exploit differences in demand because of costs of resale across markets. Our definition of increased market integration is that the costs of resale are falling relative to other costs in the economy, either because nations have reduced barriers to the free flow of goods across borders or because trans- 
port and information costs have decreased between markets. ${ }^{4}$ These definitions of price discrimination and market integration have important consequences for measurement and interpretation.

First, it is important to recognize that the degree of price dispersion we observe in the data is not purely a function of market integration. Variation in demand elasticities due to underlying variation in fundamentals such as income, exchange rates, or availability of substitutes can give rise to variation in price dispersion as well. Unfortunately, the precise link between these fundamental factors and the dispersion in demand elasticities is likely to be quite complicated and difficult to discern in the amount of data we have available. We will make no explicit attempt to control for them, but merely note their potential impact on our findings.

Second, it is important to account for the fact that resale costs may be rising in nominal terms, but falling relative to other costs. Ideally, we would like to know whether the permissible range of price dispersion is rising or falling relative to the product price itself. To capture this concept we will use the coefficient of variation $(\mathrm{CV})$, which equals the standard deviation of the prices across countries within a given period divided by the mean of prices across countries for that period. A falling $\mathrm{CV}$ will be interpreted as falling resale costs and increased integration.

We study the dispersion of prices across markets and over time for four different types of price data: German export unit values, U.S. export unit values, the Big Mac, and The Economist. Each of these samples has nominal prices, converted if necessary into units of a common currency. The data samples vary in the length of time they span (German data, 1975-87; U.S. data, 1973-87; Big Mac data, 1986-97; The Economist data, 1967-91) and the destinations they include, although in general these data measure prices in OECD countries only. It is more difficult to get comparable price data in nominal currency units for many of the less developed economies. For evidence on integration between the developed and less developed countries, which has arguably been a more important phenomenon in recent decades, we will turn to quantity data in the next section.

Table 1.1 reports the estimated linear trend in the CVs calculated for each of sixteen U.S. export unit value series from 1973 to 1987. For each industry, the $\mathrm{CV}$ is calculated for each year across the set of destinations in the sample. Then the time series of CVs for that industry are regressed on a constant and a linear time trend. The cross section of destination markets includes between five and eight countries, typically including Canada, Japan, Germany, and the United Kingdom, plus one or more other European markets. Because the set of destinations is not fixed across products, the variation in results across industries may partly reflect variation

4. It is important to measure resale costs relative to other costs in order to abstract from the effects of inflation. 
Table 1.1

Trends in U.S. Export-Price Dispersion, 1973-1987

\begin{tabular}{lrcr}
\hline Industry & Trend & Std. Error & $t$-Statistic \\
\hline Aluminum foil & 0.0383 & 0.0039 & 9.78 \\
Aluminum oxide & -0.0274 & 0.011 & -2.47 \\
Integrated circuit & 0.0068 & 0.0053 & 1.28 \\
Kraft linerboard paper & -0.0036 & 0.0020 & -1.77 \\
Autos, over 8 cylinders & 0.0108 & 0.0043 & 2.51 \\
Primary cell batteries & 0.0071 & 0.0203 & 0.35 \\
Photocopier paper & 0.0040 & 0.0067 & 0.60 \\
Putty & 0.0054 & 0.0048 & 1.14 \\
Cigarettes & 0.0102 & 0.0015 & 6.74 \\
Industrial lacquers & 0.0097 & 0.0059 & 1.63 \\
Nitrile rubber & -0.0053 & 0.0056 & -0.96 \\
Raw cotton & 0.0060 & 0.0059 & 1.02 \\
Autos, under 8 cylinders & 0.0023 & 0.0012 & 1.92 \\
Titanium dioxide & 0.0162 & 0.0128 & 1.26 \\
Bourbon whiskey & -0.0086 & 0.0035 & -2.47 \\
Yellow corn & 0.1880 & 0.0320 & 5.87 \\
\hline
\end{tabular}

Source: U.S. Department of Commerce.

Note: Each trend is the coefficient estimate of annual export-price dispersion regressed on a time trend. Annual export-price dispersion is measured as the coefficient of variation in bilateral U.S. export unit values across all destination markets. Each regression contains fourteen observations.

in the markets in the sample. If price dispersion were declining steadily, we would expect the regression to yield a negative coefficient. In fact, only four of the sixteen estimates are negative and only two of them are significant at conventional levels. About four of the positive coefficients are statistically significant.

Table 1.2 reports the analogous regressions for twenty-nine German export industries from 1975 to 1987 . The cross section of destinations is similar to that in the U.S. sample, except that the United States replaces Germany as a destination in each industry. In this sample, a small majority of cases (sixteen out of twenty-nine) show a declining trend, although only five $t$-statistics are below -2.20 , which is required for statistical significance at the 5 percent level for a two-tailed test with eleven degrees of freedom. In contrast, nine out of thirteen positive coefficients are statistically significant. One factor that may help explain the number of significant positive coefficients in this set of regressions is the overvaluation of the dollar in the second half of the data sample. In general, deutsche mark prices of shipments to the United States rose sharply relative to the deutsche mark prices of shipments to other markets during the dollar's rise from 1980 to 1985 . However, we obtained similar qualitative results when we repeated the regressions excluding the United States from the sample of German export destinations. Therefore, it is clear that the overvaluation of the dollar was not by itself responsible for the significant trend increase in price dispersion across German export markets. 
Trends in German Export-Price Dispersion, 1975-1987

\begin{tabular}{lrrr}
\hline Industry & Trend & Std. Error & $t$-Statistic \\
\hline Aluminum oxide & -0.0080 & 0.0086 & -0.92 \\
Autos, 1.5 to 2-liter & 0.0095 & 0.0024 & 3.94 \\
Autos, 2 to 3-liter & -0.0058 & 0.0012 & -4.65 \\
Autos, over 3-liter & -0.0091 & 0.0044 & -2.07 \\
Glykocides & 0.0052 & 0.0045 & 1.16 \\
Induction furnaces & -0.0169 & 0.0065 & -2.60 \\
Record players & -0.0136 & 0.0077 & -1.78 \\
Razor blades & 0.0055 & 0.0044 & 1.24 \\
Pneumatic tires & -0.0005 & 0.0021 & -0.22 \\
Platinum plating & 0.0117 & 0.0021 & 5.51 \\
Aluminum hydroxide & 0.0087 & 0.0034 & 2.52 \\
Autos, under 1.5-liter & 0.0193 & 0.0069 & 2.80 \\
Titanium pigment & -0.0143 & 0.0033 & -4.28 \\
Titanium dioxide & 0.0052 & 0.0087 & 0.60 \\
Aldehyde derivatives & -0.0211 & 0.0207 & -1.02 \\
Hydrocarbons & -0.0066 & 0.0055 & -1.19 \\
Hydrogen & 0.0080 & 0.0022 & 3.67 \\
Vitamin A & 0.0197 & 0.0078 & 2.54 \\
Vitamin C & -0.0022 & 0.0023 & -0.94 \\
Beer & -0.0081 & 0.0023 & -3.48 \\
Synthetic dyes & -0.0026 & 0.0027 & -0.97 \\
Special dyes & 0.0090 & 0.0026 & 3.41 \\
Glazed ceramic tiles & -0.0021 & 0.0030 & -0.72 \\
Calcium & -0.0234 & 0.0099 & -2.36 \\
Olive oil & -0.0064 & 0.0045 & -1.42 \\
Sandals & 0.0332 & 0.0047 & 7.08 \\
Semi-finished platinum & 0.0059 & 0.0036 & 1.63 \\
Cocoa powder & -0.0013 & 0.0045 & -0.29 \\
Women's blouses & 0.0322 & 0.0048 & 6.69 \\
\hline Stiris & & &
\end{tabular}

Source: Statistisches Bundesamt.

Note: Each trend is the coefficient estimate of annual export-price dispersion regressed on a time trend. Annual export-price dispersion is measured as the coefficient of variation in bilateral German export unit values across all destination markets.

One problem with the results for the U.S. and German exports is that in each case the data are based on unit values of shipments. The unit-value data are susceptible to quality change. If product varieties have become more specialized in a destination-specific manner over time, this may account for increasing dispersion in unit values (see Lipsey 1963 for a detailed analysis of these issues). Arbitrage forces are not as strong when product substitutability is low. While there are no comprehensive data on identical products, it is quite easy to get price data for the Big Mac and The Economist (cover or newsstand price) on a local-currency basis for a number of markets.

While Big Macs and The Economist do not strike people as classic "tradables" for which trade arbitrages away international price differentials, there 
are still good reasons to expect that prices for these goods should converge as a result of market integration. First, many of the inputs used in producing a Big Mac (flour, beef) or a magazine (paper) are in fact tradable goods. As these prices converge across countries, prices of the final goods should as well. Second, if product-market integration induces factor-price convergence across countries, then we have further reason to think the prices of these goods might converge across markets.

What do these data show us about price dispersion? Results for the Big Mac prices are reported in table 1.3 for three different samples. The first sample uses prices from twelve different markets, but excludes the 1987 observation (which is missing for half of these markets). The regression shows a slight, but insignificant, tendency for dispersion to fall over time for the ten annual data points. If we restrict the sample to the six markets for which prices are available in all eleven periods, there is an increase in the estimated convergence trend, but the coefficient is still not statistically significant. Finally, if we exclude the United States from the sample of six, the remaining five markets-Belgium, the United Kingdom, France, the Netherlands, and Germany-do show a significant trend toward lower dispersion. This might be expected since European integration is taking hold over this period and exchange rates are perhaps more tightly linked.

Results for The Economist are shown in table 1.4. These data cover the longest time span of any of our data: 1967 to 1991 . The whole sample of eleven markets shows little evidence of trend. This result does not change markedly when the United States is excluded. When the United States, the United Kingdom, and Ireland are removed from the sample, the remaining set of European and Scandinavian markets does show some tendency toward reduced dispersion. If we restrict the sample of countries to the same six used for the Big Mac, we see significantly lower dispersion over time.

What do we take away from the reported evidence on price dispersion? Basically, that there is little evidence in the data that product markets in developed economies have become more closely linked in the 1970s and 1980s. That may be a result of the fact that this set of countries was already fairly integrated by the 1970s. We do note that with the Big Mac and The

Table 1.3 Trends in Price Convergence for the Big Mac, 1986-1997

\begin{tabular}{lccc}
\hline Country Group & Trend & Std. Error & $t$-Statistic \\
\hline Big Mac 12 & -0.0014 & 0.0023 & -0.62 \\
Big Mac 6 & -0.0029 & 0.0026 & -1.14 \\
Big Mac 5 & -0.0069 & 0.0020 & -3.44 \\
\hline
\end{tabular}

Source: The Economist, various issues.

Note: Each trend is the coefficient estimate of annual price dispersion regressed on a time trend. Annual price dispersion is measured as the coefficient of variation in Big Mac prices across all countries in the country group. Country groups are defined in the text. 
Trends in Price Convergence for The Economist, 1961-1991

\begin{tabular}{lrcc}
\hline Country Group & \multicolumn{1}{c}{ Trend } & Std. Error & $t$-Statistic \\
\hline Economist 11 & 0.0003 & 0.0010 & 0.25 \\
Economist 10 & 0.0005 & 0.0010 & 0.47 \\
Economist 8 & -0.0014 & 0.0008 & -1.77 \\
Big Mac 6 & -0.0049 & 0.0012 & -4.01 \\
Big Mac 5 & -0.0028 & 0.0014 & -1.94 \\
\hline
\end{tabular}

Source: The Economist, various issues.

Note: Each trend is the coefficient estimate of annual price dispersion regressed on a time trend. Annual price dispersion is measured as the coefficient of variation in prices of The Economist across all countries in the country group. Country groups are defined in the text.

Economist there is some evidence that countries in Europe may be more closely linked today than they were ten or twenty years ago. This is not surprising.

\subsubsection{The Behavior of Relative Prices}

Our second approach to looking for integration of national economies in price data is to examine whether countries seem to be converging toward a common set of internal relative prices. This approach is appropriate for two reasons. First, resource-allocation decisions within a country are a function of relative prices. Second, the best source of information on internal relative prices for fairly detailed product categories is found in the International Comparisons Program data. This collection effort was spearheaded by a group of scholars that included Robert Lipsey.

While the ICP data exist in principle for many countries at five-year intervals from 1970 to the present, we were only able to obtain the data for 1975, 1980, and 1985. We focus on the two endpoints and ask whether the relative prices within countries are converging toward a common benchmark. This requires a choice of benchmark. Ideally one would like a "world price" that would prevail in an open market, but by definition, this does not exist. Instead, we pick individual countries as a benchmark: first the United States, then Germany.

To measure variation relative to the base country, we first normalize the data by multiplying each country's price for a given product by the reciprocal of the base-country price of that product. This is done for all products, ensuring that the price vector for the base country is a vector of ones. For each other country in the sample, we compute the coefficient of variation of the prices across individual products. If the country has a relative price structure identical to that of the base country, the $\mathrm{CV}$ will equal zero, since the price vector will be a constant. Specifically, each element of the price vector for a particular country would be equal to the exchange rate (local currency per unit of base-country currency) between the particular coun- 
try and the base country that prevailed for this set of products. Since that exchange rate need not equal the actual market exchange rate, prices in the two countries need not be equal to have a common relative price structure. ${ }^{5}$ On the other hand, as prices within a country depart from the crosscategory mean price, the $\mathrm{CV}$ rises.

Table 1.5 reports the $\mathrm{CV}$ of internal relative prices for seventeen countries in 1975 and 1985 benchmarked against the U.S. relative price structure. The CV is calculated for two separate groupings of goods - producer goods and consumer goods - and for the total. ${ }^{6}$ The measure for producer goods is based on a sample of only three products and should be judged accordingly. The cross-country variation in the CVs seems to correlate with stages of economic development. Most developed countries in the sample have lower CVs than the less developed countries. ${ }^{7}$ This might reflect the different degrees of nontraded services included in product prices, especially for certain consumer goods.

Turning to the time dimension of the U.S.-benchmarked sample, there is a large decline in the calculated CVs between 1975 and 1985 for Korea and India, and to a lesser extent for Japan, Belgium, and France. This suggests some convergence toward common relative prices between the United States and these countries. On the other hand, the CVs for the Philippines and Thailand increase by large amounts between the two periods, suggesting a movement toward more diverse relative prices vis-à-vis the United States. Overall, this relative-price evidence shows that linkages are much closer between the United States and the other developed countries than they are between the United States and developing countries. Furthermore, the big movements in relative prices suggest either convergence or roughly no change with respect to some developed countries, while there are signs of convergence and divergence with respect to the set of developing countries.

Turning to the German-benchmarked sample (see table 1.6), one feature that stands out is how small the CVs are vis-à-vis other continental European countries. It seems that relative prices within Europe were already quite close to the relative prices in Germany. The only notable changes

5. It is easy to imagine how a sudden currency swing might cause systematic violations in the law of one price without necessarily altering the relative price structure between two markets.

6. Note that the CV for the total is not equal to the average of the two subgroups. This is primarily because the two subgroups may have different means. Looking within the subgroup does not capture this additional source of change in the overall coefficient of variation.

7. The raw data also reveal another interesting feature: The less developed countries tend to have higher relative prices for producer vs. consumer goods relative to the United States. Other developed countries' distortions relative to U.S. prices seem to be unrelated to the broad groupings of producer and consumer goods. We note that some of the developing countries (e.g., Poland) had extensive government intervention in product markets during our sample period. That said, however, we have chosen to include countries with available data without making judgments about this issue. 


\begin{tabular}{|c|c|c|c|c|c|c|}
\hline \multirow[b]{2}{*}{ Country } & \multicolumn{3}{|c|}{1975} & \multicolumn{3}{|c|}{1985} \\
\hline & $\begin{array}{c}\text { All } \\
\text { Goods }\end{array}$ & $\begin{array}{l}\text { Consumer } \\
\text { Goods }\end{array}$ & $\begin{array}{l}\text { Producer } \\
\text { Goods }\end{array}$ & $\begin{array}{c}\text { All } \\
\text { Goods }\end{array}$ & $\begin{array}{l}\text { Consumer } \\
\text { Goods }\end{array}$ & $\begin{array}{c}\text { Producer } \\
\text { Goods }\end{array}$ \\
\hline Austria & 0.23 & 0.20 & 0.10 & 0.21 & 0.22 & 0.18 \\
\hline Belgium & 0.28 & 0.30 & 0.14 & 0.18 & 0.18 & 0.19 \\
\hline Denmark & 0.27 & 0.29 & 0.20 & 0.30 & 0.30 & 0.28 \\
\hline France & 0.26 & 0.28 & 0.09 & 0.19 & 0.19 & 0.20 \\
\hline Germany & 0.23 & 0.23 & 0.23 & 0.24 & 0.25 & 0.16 \\
\hline India & 0.69 & 0.79 & 0.07 & 0.42 & 0.41 & 0.13 \\
\hline Ireland & 0.33 & 0.36 & 0.15 & 0.31 & 0.33 & 0.27 \\
\hline Italy & 0.30 & 0.31 & 0.13 & 0.26 & 0.28 & 0.20 \\
\hline Japan & 0.37 & 0.37 & 0.28 & 0.29 & 0.29 & 0.15 \\
\hline Kenya & 0.47 & 0.42 & 0.20 & 0.46 & 0.48 & n.a. \\
\hline Korea & 0.76 & 0.83 & 0.20 & 0.38 & 0.39 & 0.34 \\
\hline Netherlands & 0.23 & 0.22 & 0.17 & 0.29 & 0.31 & 0.18 \\
\hline Philippines & 0.61 & 0.61 & 0.20 & 0.88 & 0.36 & 1.02 \\
\hline Poland & 0.37 & 0.41 & 0.12 & 0.35 & 0.34 & 0.41 \\
\hline Spain & 0.26 & 0.25 & 0.04 & 0.26 & 0.26 & 0.22 \\
\hline Thailand & 0.48 & 0.42 & 0.12 & 0.60 & 0.47 & 0.16 \\
\hline United Kingdom & 0.35 & 0.38 & 0.06 & 0.30 & 0.31 & 0.26 \\
\hline
\end{tabular}

Source: International Comparisons Program, from World Bank (1993).

Note: Each cell reports the coefficient of variation in the country's price basket. For each product, price levels have been normalized worldwide such that the U.S. price equals one. n.a. = not available.

Table 1.6

Dispersion in National Relative Prices Relative to German Relative Prices

\begin{tabular}{|c|c|c|c|c|c|c|}
\hline \multirow[b]{2}{*}{ Country } & \multicolumn{3}{|c|}{1975} & \multicolumn{3}{|c|}{1985} \\
\hline & $\begin{array}{c}\text { All } \\
\text { Goods }\end{array}$ & $\begin{array}{l}\text { Consumer } \\
\text { Goods }\end{array}$ & $\begin{array}{l}\text { Producer } \\
\text { Goods }\end{array}$ & $\begin{array}{c}\text { All } \\
\text { Goods }\end{array}$ & $\begin{array}{l}\text { Consumer } \\
\text { Goods }\end{array}$ & $\begin{array}{c}\text { Producer } \\
\text { Goods }\end{array}$ \\
\hline Austria & 0.22 & 0.19 & 0.28 & 0.12 & 0.12 & 0.14 \\
\hline Belgium & 0.16 & 0.17 & 0.10 & 0.15 & 0.16 & 0.05 \\
\hline Denmark & 0.18 & 0.16 & 0.31 & 0.19 & 0.18 & 0.27 \\
\hline France & 0.17 & 0.18 & 0.16 & 0.15 & 0.17 & 0.05 \\
\hline India & 0.61 & 0.69 & 0.14 & 0.58 & 0.63 & 0.26 \\
\hline Ireland & 0.28 & 0.28 & 0.30 & 0.26 & 0.28 & 0.21 \\
\hline Italy & 0.22 & 0.22 & 0.20 & 0.16 & 0.17 & 0.11 \\
\hline Japan & 0.48 & 0.46 & 0.45 & 0.34 & 0.35 & 0.03 \\
\hline Kenya & 0.46 & 0.37 & 0.37 & 0.38 & 0.38 & n.a. \\
\hline Korea & 0.96 & 1.03 & 0.30 & 0.48 & 0.51 & 0.40 \\
\hline Netherlands & 0.12 & 0.11 & 0.08 & 0.12 & 0.12 & 0.08 \\
\hline Philippines & 0.60 & 0.61 & 0.37 & 0.97 & 0.48 & 1.09 \\
\hline Poland & 0.35 & 0.37 & 0.29 & 0.46 & 0.47 & 0.39 \\
\hline Spain & 0.44 & 0.48 & 0.21 & 0.25 & 0.24 & 0.20 \\
\hline Thailand & 0.49 & 0.52 & 0.16 & 0.73 & 0.69 & 0.27 \\
\hline United Kingdom & 0.25 & 0.27 & 0.15 & 0.21 & 0.22 & 0.20 \\
\hline United States & 0.31 & 0.32 & 0.21 & 0.22 & 0.24 & 0.14 \\
\hline
\end{tabular}

Source: International Comparisons Program, from World Bank (1993).

Note: Each cell reports the coefficient of variation in the country's price basket. For each product, price levels have been normalized worldwide such that the German price equals one. n.a. $=$ not available. 
among this set of countries were declines by Austria and Italy. Price dispersion is somewhat greater vis-à-vis the United Kingdom and Ireland, with only slight declines in the CVs over the decade. Looking outside European markets, we see that CVs declined markedly for Japan, Kenya, Korea, and the United States. They rose for the Philippines, Poland, and Thailand. This evidence seems broadly consistent with what was observed in the U.S. sample. Relative prices are much more similar within the developed economies, and the main tendency among developed markets is toward further convergence of prices. However, with developing countries, we see cases of both convergence and divergence over this decade.

Taken together, the totality of price evidence we have examined here points to increased linkages between the developed economies over recent decades, especially within the European markets, which were already quite closely integrated with each other. It is more difficult to tell what the price evidence says about integration between developed and developing countries, partly due to lack of data. For the data we have at present, the results are mixed.

\subsection{Evidence from Quantities}

\subsubsection{Market "Thickness": Evidence from Trade Flows}

Our first quantity-based integration measure looks at how "thick" product markets are in terms of breadth of trade flows. Define the categorical variable $Z_{i j k t}$ to be equal to one if country $j$ has some positive value of exports to country $k$ in industry $i$ during year $t$, and zero otherwise. If there are $N$ countries in the world at time $t$, then for each industry $i$ there can be up to $[(N) \times(N-1)]$ total bilateral trade flows. One possible measure of market "thickness" might be the share of total possible bilateral trade flows for which trade actually happens. This thickness measure can be calculated for each industry-year as follows:

$$
\theta_{i t}+\left\{\frac{{ }_{j} \cdot{ }_{k \cdot j} Z_{i k t}}{[(N) \times(N-1)]_{t}}\right\} .
$$

By construction, the thickness measure $\theta_{i t}$ ranges from zero to one and reports the share of total possible bilateral trade "hits" in which trade actually happened. If every (no) country-pair worldwide has two-way trade in industry $i$ at time $t$, then $\theta_{i t}$ equals one (zero). We interpret higher values of $\theta_{i t}$ to indicate a thicker world market. In accounting for the incidence of trade (i.e., because $Z_{i j k t}$ is categorical), note that this measure does not incorporate any information about trade volumes. Given this property, we intend for this measure to capture the competitiveness of product markets under the assumption that competitiveness depends "on 
the margin" on the incidence of trade regardless of the volume of that trade. We hypothesize that globalization might increase market thickness over time, insofar as lower trade barriers permit more bilateral trade hits. Of course, lower barriers might have countervailing effects as well: If national production mixes become more specialized, for some industries there might be fewer exporters and thus fewer bilateral trade hits. Whatever the case, we think the $\theta_{i t}$ measure is informative.

To construct $\theta_{i t}$ we use the world trade data in Feenstra, Lipsey, and Bowen (1997). These data cover thirty-four manufacturing industries (as defined by the Bureau of Economic Analysis) from 1970 through 1992. We try two different sets of countries: the twenty-four original OECD countries, and "the world" defined as 122 countries with trade data available for all twenty-three years of the sample. In addition, each observation of $\theta_{i t}$ from the world group of countries is decomposed into four components: exports from an OECD country to another OECD country $(o o)$; exports from an OECD country to a non-OECD country (on); exports from a non-OECD country to an OECD country (no); and exports from a non-OECD country to a non-OECD country $(n n)$. That is, for each industry-year observation of the world sample:

$$
\theta_{i t}=\theta_{\text {ioot }}+\theta_{\text {iont }}+\theta_{\text {inot }}+\theta_{\text {innt }} \text {. }
$$

Each of the four components is constructed by varying the countries $j$ and $k$ in $Z_{i j k t}$. For example, for $\theta_{i o n t}$ the set of $j$ exporting countries is the OECD and the set of $k$ importing countries is the non-OECD. By keeping $N=$ 122 for all four components we end up with equation (2). With this decomposition, we can see how changes in $\theta_{i t}$ are accounted for by major country groupings. ${ }^{8}$

Table 1.7 reports some summary statistics for the OECD sample, the world sample, and the four components of the world sample. Note that on average, markets are much thicker within the OECD sample than within the broader sample. This squares with the general fact that most world trade is among OECD countries. Within the world sample, note that total exports from non-OECD countries account for about two-thirds of all bilateral trade "hits." These summary statistics mask a lot of heterogeneity across industries. Table 1.8 reports the mean thickness indexes for all thirty-four industries for both the OECD and full-world samples. Over the full time series, in both samples tobacco products is the thinnest market ( 0.53 in the OECD, 0.07 in the world) while miscellaneous food products is the thickest market ( 0.97 in the OECD, 0.31 in the world).

8. One concern we have in constructing our trade-thickness measures is whether the raw data contain threshold levels of trade required for a nonzero entry and, relatedly, how these threshold levels change over time. Any discrete changes in thresholds might cause discrete changes in trade thickness. The available data documentation did not flag any problems here, but we highlight the issue nevertheless. 
Table 1.7

Summary Statistics for Trade-Thickness Measures

\begin{tabular}{ccccc}
\hline Variable & Mean & $\begin{array}{c}\text { Std. } \\
\text { Deviation }\end{array}$ & Minimum & Maximum \\
\hline$\theta_{\text {it }}$ OECD & 0.851 & 0.088 & 0.496 & 0.994 \\
$\theta_{\text {it }}$ World & 0.200 & 0.054 & 0.061 & 0.362 \\
$\theta_{\text {ioot }}$ & 0.029 & 0.003 & 0.017 & 0.034 \\
$\theta_{\text {iont }}$ & 0.035 & 0.016 & 0.005 & 0.089 \\
$\theta_{\text {inot }}$ & 0.082 & 0.018 & 0.028 & 0.122 \\
$\theta_{\text {innt }}$ & 0.054 & 0.022 & 0.009 & 0.135 \\
\hline
\end{tabular}

Source: Feenstra, Lipsey, and Bowen (1997).

Note: These variables are trade-thickness measures as defined by equations (1) and (2) in the text. The sample contains 782 observations ( 34 industries $\times 23$ years).

To see how market thickness has evolved over time, we pooled the industry thickness measures and regressed them on a full set of industry dummy variables (ID, which control for time-invariant differences in market integration across industries) and a time trend:

$$
\theta_{i t}=\alpha(\mathrm{ID})_{i}+\beta t+e_{i t},
$$

where $e_{i t}$ is an additive error term. For both our thickness measures (OECD and world) the time trend in equation (3) had a significantly positive coefficient estimate, suggesting that markets have been thickening over time. Regressions with a time trend, however, do not allow us to see whether the pace of integration has varied over time. To do this we replace the time trend in equation (3) with a full set of time dummies (TD) and estimate equation $\left(3^{\prime}\right)$ :

$$
\theta_{i t}=\alpha(\mathrm{ID})_{i}+\beta(\mathrm{TD})_{t}+u_{i t} .
$$

Table 1.9 reports the parameter estimates on the time dummies from equation (3') using the world sample and all six thickness measures: those from the OECD sample, those from the world sample, and the four world components as described in equation (2). The key message of table 1.9 is that the market-thickening process looked very different in the 1970s and 1980s. During the 1970s the coefficients on the time dummies increased almost uniformly for all six thickness measures. This indicates that market thickening proceeded continually throughout the 1970s.

The 1980s looked very different, however. After 1979 the coefficients on the time dummies decreased for some time, and only after some additional time did they return to their 1979 level. This suggests that market thickening proceeded much less uniformly during the 1980s. The extent of this thickening slowdown varies among thickness measures. Among the OECD countries the slowdown lasted the shortest period: For the OECD-sample $\theta_{i t}$ the time dummies return to their 1979 levels in 1984, and for $\theta_{i o o t}$ the 
Average Trade-Thickness Measures by Industry

\begin{tabular}{lcc}
\hline Industry Name & $\theta_{i t}$ OECD & $\theta_{i t}$ World \\
\hline Grain-mill and bakery products & 0.780 & 0.147 \\
Beverages & 0.832 & 0.162 \\
Tobacco products & 0.535 & 0.072 \\
Miscellaneous food products & 0.974 & 0.308 \\
Apparel and textile products & 0.967 & 0.307 \\
Leather products & 0.877 & 0.200 \\
Pulp, paper, and board mills & 0.801 & 0.168 \\
Other paper products & 0.834 & 0.177 \\
Printing and publishing & 0.874 & 0.188 \\
Drugs & 0.863 & 0.218 \\
Soaps, cleaners, and toilet goods & 0.789 & 0.153 \\
Agricultural chemicals & 0.672 & 0.145 \\
Industrial chemicals and synthetics & 0.914 & 0.258 \\
Other chemical products & 0.885 & 0.218 \\
Rubber products & 0.852 & 0.197 \\
Miscellaneous plastic products & 0.889 & 0.191 \\
Ferrous metal products & 0.836 & 0.182 \\
Nonferrous metal products & 0.908 & 0.219 \\
Fabricated metal products & 0.926 & 0.257 \\
Farm and garden machinery & 0.785 & 0.124 \\
Construction, mining, and related machinery & 0.836 & 0.189 \\
Computer and office equipment & 0.835 & 0.167 \\
Other nonelectric machinery & 0.932 & 0.278 \\
Household appliances & 0.841 & 0.177 \\
Audio, video, and communication equipment & 0.892 & 0.222 \\
Electronic components and accessories & 0.762 & 0.115 \\
Other electrical machinery & 0.897 & 0.236 \\
Motor vehicles and equipment & 0.858 & 0.228 \\
Other transportation equipment & 0.839 & 0.188 \\
Lumber, wood, furniture, and fixtures & 0.857 & 0.214 \\
Glass products & 0.845 & 0.178 \\
Stone, clay, and other mineral products & 0.889 & 0.210 \\
Instruments and related products & 0.898 & 0.248 \\
Other manufactures & 0.948 & 0.254 \\
& & \\
\hline
\end{tabular}

Source: Feenstra, Lipsey, and Bowen (1997).

Note: These variables are average trade-thickness measures as defined by equation (1) in the text. The sample contains 782 observations ( 34 industries $\times 23$ years).

1979 level held steady until 1985. Trade flows involving non-OECD countries took longer to rebound - particularly exports from non-OECD countries. For the world-sample $\theta_{i t}$ the time dummies do not return to the 1979 level until 1988. The other three components of the world-sample $\theta_{i t}$ returned as follows: $\theta_{\text {iont }} 1986, \theta_{\text {inot }} 1989$, and $\theta_{\text {innt }}$ 1988. Figure 1.2 summarizes the difference across decades for all manufacturing together by averaging $\theta_{i t}$ across all thirty-four industries in each year. The rise in the $1970 \mathrm{~s}$ and subsequent stalling in the 1980s is clear. Figure 1.3 shows the same 


\begin{tabular}{lcccccc}
\hline & $\theta_{i t}$ OECD & $\theta_{\text {it }}$ World & $\theta_{\text {ioot }}$ & $\theta_{\text {iont }}$ & $\theta_{\text {inot }}$ & $\theta_{\text {innt }}$ \\
\hline 1970 & 0.899 & 0.223 & 0.031 & 0.049 & 0.081 & 0.062 \\
1971 & 0.909 & 0.227 & 0.031 & 0.050 & 0.082 & 0.064 \\
1972 & 0.918 & 0.232 & 0.031 & 0.051 & 0.083 & 0.066 \\
1973 & 0.933 & 0.239 & 0.032 & 0.054 & 0.085 & 0.068 \\
1974 & 0.936 & 0.244 & 0.032 & 0.054 & 0.086 & 0.071 \\
1975 & 0.933 & 0.246 & 0.032 & 0.055 & 0.087 & 0.073 \\
1976 & 0.935 & 0.248 & 0.032 & 0.055 & 0.087 & 0.074 \\
1977 & 0.935 & 0.253 & 0.032 & 0.056 & 0.089 & 0.076 \\
1978 & 0.939 & 0.264 & 0.032 & 0.058 & 0.095 & 0.079 \\
1979 & 0.942 & 0.265 & 0.032 & 0.059 & 0.095 & 0.079 \\
1980 & 0.929 & 0.248 & 0.032 & 0.054 & 0.089 & 0.072 \\
1981 & 0.933 & 0.248 & 0.032 & 0.055 & 0.089 & 0.072 \\
1982 & 0.933 & 0.247 & 0.032 & 0.055 & 0.090 & 0.070 \\
1983 & 0.936 & 0.244 & 0.032 & 0.055 & 0.089 & 0.068 \\
1984 & 0.944 & 0.244 & 0.032 & 0.055 & 0.090 & 0.066 \\
1985 & 0.951 & 0.249 & 0.033 & 0.056 & 0.092 & 0.068 \\
1986 & 0.962 & 0.256 & 0.033 & 0.059 & 0.092 & 0.072 \\
1987 & 0.971 & 0.263 & 0.033 & 0.061 & 0.094 & 0.075 \\
1988 & 0.983 & 0.269 & 0.034 & 0.064 & 0.093 & 0.079 \\
1989 & 0.989 & 0.275 & 0.034 & 0.064 & 0.095 & 0.081 \\
1990 & 0.998 & 0.283 & 0.034 & 0.065 & 0.096 & 0.087 \\
1991 & 1.001 & 0.284 & 0.034 & 0.065 & 0.095 & 0.089 \\
1992 & 1.004 & 0.293 & 0.034 & 0.068 & 0.098 & 0.093 \\
\hline
\end{tabular}

Source: Feenstra, Lipsey, and Bowen (1997).

Note: Each column is a different trade-thickness measure as defined in equations (1) and (2) in the text. For each thickness measure, each row reports the coefficient estimate on that year's time dummy variable from regression equation $\left(3^{\prime}\right)$. All regressions contain 782 observations.

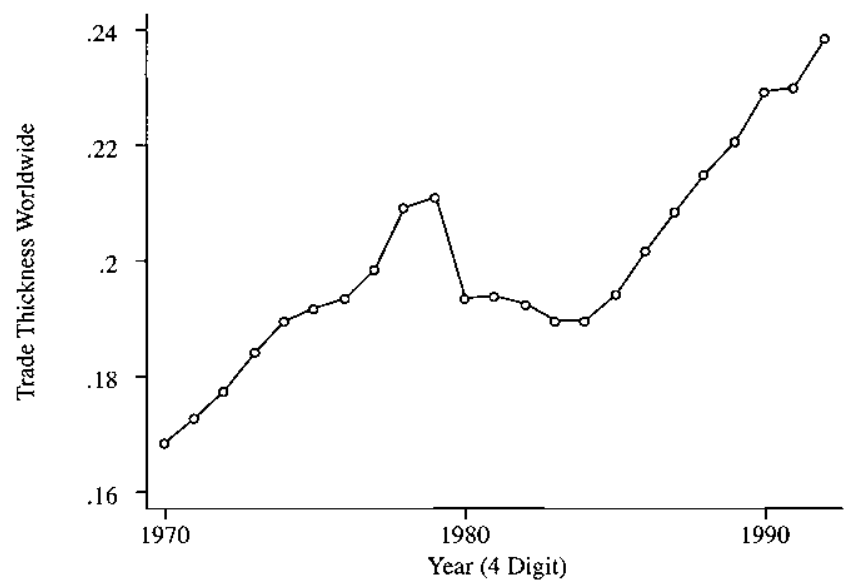

Fig. 1.2 World trade thickness: all manufacturing

Source: Feenstra, Lipsey, and Bowen (1997).

Note: Each year plots the thickness of world trade (as defined in eq. [1]) averaged across all thirty-four manufacturing industries. 




Fig. 1.3 World trade thickness: textiles and apparel

Source: Feenstra, Lipsey, and Bowen (1997).

Note: Each year plots the thickness of world trade (as defined in eq. [1]) for the textiles and apparel industry.

pattern for a single industry, textiles and apparel. The pattern in this figure is repeated in many other industries; altogether they give rise to figure 1.2.

In interpreting regression results from equation ( $\left.3^{\prime}\right)$ as evidence of integration, we reiterate our caveat that our analysis does not link outcomes back to trade barriers. Without these links we cannot rule out the possibility that changes in outcomes are caused by forces other than declining barriers, such as economic growth. To address this issue we reestimated equation ( $\left.3^{\prime}\right)$ by adding in additional regressors to control for forces affecting $\theta_{i t}$ other than declining barriers as proxied by time dummies. Our choice of regressors, as with our empirical strategy more generally, does not follow from a specific trade model. Instead, we chose measures aimed at capturing cross-country differences in endowments, tastes, technology, and the resulting international dispersion of production.

In table 1.10 we report estimation results for equation $\left(3^{\prime}\right)$ augmented by three alternative controls: cross-country dispersion in capital-to-labor endowment ratios, cross-country dispersion in GDP per worker, and crosscountry dispersion in industry production. We intend for these three controls to capture the role of endowments, of tastes and technology, and of the equilibrium international dispersion of production, respectively. The first two controls vary only over time; both come from the Penn World Tables assembled by Summers and Heston (1997). The third control is from UNIDO (1995); it varies by both time and industry. For each control, the dispersion of the variable of interest is constructed as the standard deviation of the log of that variable calculated by pooling across the rele- 
Time-Series Trends in Trade-Thickness Measures: Specifications with Controls

\begin{tabular}{|c|c|c|c|c|c|c|}
\hline & \multicolumn{3}{|c|}{$\theta_{i t} \mathrm{OECD}$} & \multicolumn{3}{|c|}{$\theta_{i t}$ World } \\
\hline & \multicolumn{3}{|c|}{ Per Capita } & \multicolumn{3}{|c|}{ Per Capita } \\
\hline & Endowments & GDP & Output & Endowments & GDP & Output \\
\hline 1970 & n.a. & n.a. & 0.876 & -0.055 & n.a. & 0.232 \\
\hline 1971 & 0.030 & 0.052 & 0.888 & -0.049 & 0.005 & 0.236 \\
\hline 1972 & 0.058 & 0.086 & 0.898 & -0.042 & 0.007 & 0.240 \\
\hline 1973 & 0.096 & 0.107 & 0.914 & -0.033 & 0.012 & 0.246 \\
\hline 1974 & 0.118 & 0.129 & 0.918 & -0.026 & 0.017 & 0.251 \\
\hline 1975 & 0.126 & 0.167 & 0.916 & -0.022 & 0.019 & 0.253 \\
\hline 1976 & 0.139 & 0.182 & 0.917 & -0.019 & 0.018 & 0.255 \\
\hline 1977 & 0.148 & 0.207 & 0.918 & -0.012 & 0.024 & 0.260 \\
\hline 1978 & 0.168 & 0.205 & 0.922 & 0.001 & 0.036 & 0.270 \\
\hline 1979 & 0.180 & 0.200 & 0.926 & 0.006 & 0.037 & 0.272 \\
\hline 1980 & 0.174 & 0.182 & 0.914 & -0.008 & 0.012 & 0.254 \\
\hline 1981 & 0.184 & 0.186 & 0.917 & -0.006 & 0.017 & 0.255 \\
\hline 1982 & 0.189 & 0.200 & 0.917 & -0.007 & 0.018 & 0.253 \\
\hline 1983 & 0.196 & 0.204 & 0.919 & -0.011 & 0.016 & 0.251 \\
\hline 1984 & 0.205 & 0.200 & 0.927 & -0.013 & 0.015 & 0.251 \\
\hline 1985 & 0.209 & 0.209 & 0.935 & -0.011 & 0.024 & 0.256 \\
\hline 1986 & 0.220 & 0.235 & 0.947 & -0.002 & 0.029 & 0.263 \\
\hline 1987 & 0.229 & 0.260 & 0.956 & -0.001 & 0.036 & 0.269 \\
\hline 1988 & 0.241 & 0.268 & 0.968 & 0.001 & 0.039 & 0.275 \\
\hline 1989 & 0.252 & 0.282 & 0.974 & 0.007 & 0.044 & 0.281 \\
\hline 1990 & 0.263 & 0.341 & 0.982 & 0.012 & 0.055 & 0.290 \\
\hline 1991 & 0.294 & n.a. & 0.986 & 0.002 & n.a. & 0.291 \\
\hline 1992 & 0.339 & n.a. & 0.988 & n.a. & n.a. & 0.300 \\
\hline
\end{tabular}

Source: Feenstra, Lipsey, and Bowen (1997), Summers and Heston (1997), UNIDO (1995).

Note: Each column is a different trade-thickness measure as defined in equation (1) in the text. For each thickness measure, each row reports the coefficient estimate on that year's time dummy variable from regression equation ( $\left.3^{\prime}\right)$, expanded to include the control regressor. Exact definitions of control variables are given in the text. All regressions contain 782 observations. n.a. $=$ not available.

vant set of countries (i.e., the set of countries used in the thickness measure-either the OECD or the 122 countries in "the world").9

Table 1.10 reports results for six regressions: three for the OECD and three for the world, each estimates of equation ( $\left.3^{\prime}\right)$ plus one of the control regressors..$^{10}$ The key message of this table is that the time-series patterns in our thickness measures appear robust to controlling for other plausible determinants of thickness. In all but one case, the general pattern remains

9. For our third control, the UNIDO data contain 28 three-digit International Standard Industrial Classification (ISIC) manufacturing industries. Our thickness measures are constructed for the thirty-four BEA manufacturing industries. We matched the UNIDO industries to the BEA industries as best we could without a true concordance; accordingly, we acknowledge that this procedure introduced some measurement error.

10 . For the world sample, in the interest of brevity we report using just total world tradehits thickness measure-i.e., only the left-hand side of equation (2). 
Changes in World Trade Thickness

\begin{tabular}{lcccc}
\hline Thickness Measure & $\theta_{\text {ioot }}$ & $\theta_{\text {iont }}$ & $\theta_{\text {inot }}$ & $\theta_{\text {innt }}$ \\
\hline Level in 1970 & 0.028 & 0.028 & 0.074 & 0.044 \\
Level in 1992 & 0.031 & 0.048 & 0.090 & 0.075 \\
Change in level, 1970-92 & 0.003 & 0.020 & 0.016 & 0.031 \\
Share of $\Delta \theta_{i t}$ world & 0.054 & 0.284 & 0.223 & 0.439 \\
\hline
\end{tabular}

Source: Feenstra, Lipsey, and Bowen (1997).

Note: These levels and changes for each measure are averaged across all 34 industries in the sample. The thickness measures are defined in equation (2).

of rising thickness over the 1970s followed by a decline and then recovery in thickness over part or most of the 1980s. Only for the OECD sample using endowment dispersion do we find a much shorter decline period. As for the controls, both endowment and per capita GDP dispersion were very significantly positive in all specifications. The industry-output control was significantly positive at the 10 percent level for the OECD sample, but significantly negative at that level for the world sample.

Finally, table 1.11 reports how the worldwide trade thickening from 1970 to 1992 was allocated across the four components in equation (2). For each of the four components table 1.11 reports the level in 1970 and 1992, the level change between 1970 and 1992, and finally the share of the total level change in $\theta_{i t}$ accounted for by that component, all averaged in each year across the thirty-four industries. Slightly less than half of the total increase in $\theta_{i t}$ was accounted for by trade among non-OECD countries. About 28 percent was accounted for by exports from the OECD to non-OECD countries, while another 22 percent was accounted for by trade in the other direction. Only about 5 percent of the total increase was accounted for by trade among OECD countries.

\subsubsection{The Geographic Dispersion of Production}

Our second quantity-based integration measure is the degree of production concentration worldwide, measured with industry-year Herfindahl indexes of production. Let $X_{j i t}$ be the output of country $j$ in industry $i$ at time $t$. Then we define the following:

$$
\operatorname{Herf} X_{i t}+\cdot_{j}\left(\frac{X_{j i t}}{X_{\text {worldit }}}\right)^{2} .
$$

By construction, $\operatorname{Herf} X_{i t}$ ranges from zero to one. It equals one if a single country produces all the world's output in some industry-year, and it approaches zero as world production is spread evenly across all countries. In a standard HO model Herf $X_{i t}$ should increase with integration as world production becomes more specialized according to comparative 
Table 1.12

Summary Statistics for World Production Dispersion

\begin{tabular}{lcccc}
\hline Variable & Mean & $\begin{array}{c}\text { Std. } \\
\text { Deviation }\end{array}$ & Minimum & Maximum \\
\hline Value-added Herf $X_{i t}$ & 0.164 & 0.063 & 0.064 & 0.465 \\
Gross-output Herf $X_{i t}$ & 0.133 & 0.045 & 0.056 & 0.346 \\
\hline
\end{tabular}

Source: UNIDO (1995).

Note: These variables are Herfindahl indexes of production dispersion as defined by equation (4) in the text. The sample contains 644 observations ( 28 industries $\times 23$ years).

advantage. In an HO-fragmentation world Herf $X_{i t}$ might decline as production activities within industries spread across more countries. To construct Herf $X_{i t}$ we use data from UNIDO (1995) covering the 28 three-digit ISIC manufacturing industries from 1970 through 1992, with "the world" defined as all countries with output data available for all twenty-three years of the sample. We have information on both value added and gross output; for completeness we use both, and thus measure $X_{j i t}$ in terms of either value added or gross output. ${ }^{11}$

Table 1.12 reports summary statistics for the two Herfindahl indexes. Note that, on average, $\operatorname{Herf} X_{i t}$ is slightly larger for value-added output than for gross output. To see how these indexes evolved over time we pooled all observations and regressed each $\operatorname{Herf} X_{i t}$ on a full set of industry dummy variables (which control for time-invariant differences in market integration across industries) and a time trend:

$$
\operatorname{Herf} X_{i t}=\alpha(\mathrm{ID})_{i}+\beta t+e_{i t},
$$

where $e_{i t}$ is an additive error term. For both our output measures the time trend in equation (5) had a significantly negative coefficient estimate, suggesting that world production has become less concentrated over time. As before, however, regressions with a time trend do not allow us to see whether the pace of integration has varied over time. To do this we estimate equation (6).

$$
\operatorname{Herf} X_{i t}=\alpha(\mathrm{ID})_{i}+\beta(\mathrm{TD})_{t}+u_{i t},
$$

where, as before, TD is a full set of time dummies.

Table 1.13 reports the parameter estimates on the time dummies from equation (6) for both measures of Herf $X_{i t}$. For each measure, table 1.13 also reports results for equation (6) modified by adding the worldendowment-dispersion control. As with trade thickness, here, too, the

11. Strictly speaking, the standard HO model refers to industry net outputs. We have data on value added and gross output, and we assume that the Herfindahl indexes rise for these output measures whenever it rises in terms of net output. 
Time-Series Trends in World Production Dispersion

\begin{tabular}{cccccc}
\hline & \multicolumn{2}{c}{ Gross-Output Herf $X_{i t}$} & & \multicolumn{2}{c}{ Value-Added Herf $X_{i t}$} \\
\cline { 2 - 3 } \cline { 5 - 6 } & None & Endowments & & None & Endowments \\
\hline 1970 & 0.233 & 0.081 & & 0.255 & 0.078 \\
1971 & 0.214 & 0.063 & & 0.250 & 0.074 \\
1972 & 0.206 & 0.057 & & 0.242 & 0.067 \\
1973 & 0.195 & 0.046 & & 0.222 & 0.048 \\
1974 & 0.185 & 0.038 & & 0.211 & 0.038 \\
1975 & 0.179 & 0.032 & & 0.198 & 0.027 \\
1976 & 0.181 & 0.035 & 0.205 & 0.034 \\
1977 & 0.174 & 0.030 & 0.206 & 0.036 \\
1978 & 0.171 & 0.027 & 0.203 & 0.035 \\
1979 & 0.164 & 0.022 & & 0.197 & 0.031 \\
1980 & 0.157 & 0.018 & 0.181 & 0.017 \\
1981 & 0.166 & 0.027 & 0.196 & 0.033 \\
1982 & 0.167 & 0.028 & 0.200 & 0.037 \\
1983 & 0.171 & 0.031 & 0.203 & 0.039 \\
1984 & 0.172 & 0.031 & 0.209 & 0.044 \\
1985 & 0.172 & 0.030 & 0.210 & 0.044 \\
1986 & 0.159 & 0.018 & 0.192 & 0.026 \\
1987 & 0.158 & 0.014 & 0.193 & 0.024 \\
1988 & 0.156 & 0.009 & 0.187 & 0.016 \\
1989 & 0.152 & 0.009 & 0.185 & 0.013 \\
1990 & 0.154 & 0.006 & 0.180 & 0.006 \\
1991 & 0.148 & 0.006 & 0.181 & 0.000 \\
1992 & 0.160 & n.a. & 0.187 & n.a. \\
\hline & & & &
\end{tabular}

Source: UNIDO (1995) and Summers and Heston (1997).

Note: Each column is a Herfindahl index of production dispersion as defined in equation (4) in the text. For each dispersion measure, each row reports the coefficient estimate on that year's time dummy variable from regression equation (6). Exact definition of control variable is given in the text. All regressions contain 644 observations. n.a. = not available.

1970s and 1980s look different. Both measures of Herf $X_{i t}$ had uniformly declining time dummies during the 1970s. But this trend reversed after 1980 , with the time dummies increasing for several years before coming down again. This pattern holds even controlling for the world distribution of endowments (similar results were obtained using the other controls described earlier; for brevity we omit these). Figure 1.4 displays the difference across decades for all manufacturing together by averaging the grossoutput Herf $X_{i t}$ across all twenty-eight industries in each year. The fall in the 1970s and subsequent stalling in the 1980s is clear.

What these time-series patterns in $\operatorname{Herf} X_{i t}$ say about integration depends on which framework is applied. From the standard HO perspective the patterns suggest no integration in the 1970s, then greater integration in the 1980s. From the HO-fragmentation perspective the opposite is suggested: marked integration during the 1970s and then very little integration in the 


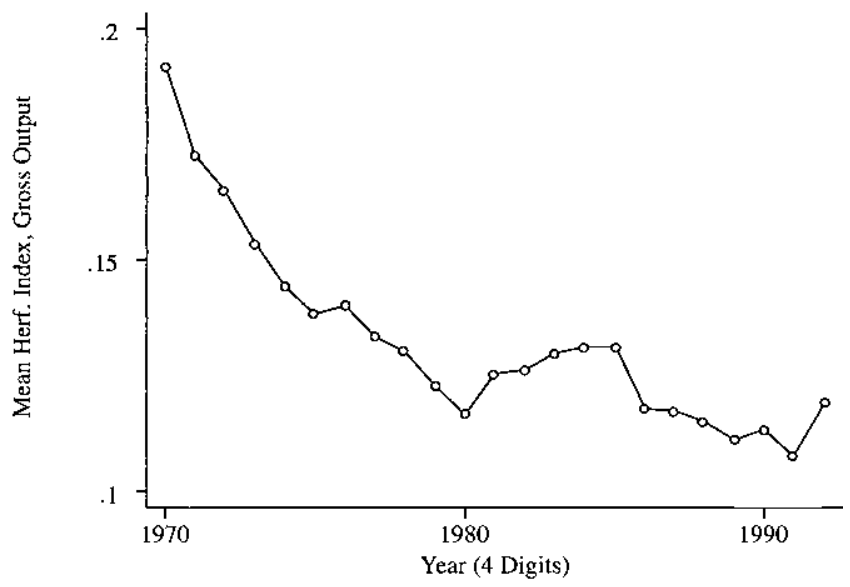

Fig. 1.4 World production dispersion: all manufacturing Source: UNIDO (1995).

Note: Each year plots the dispersion of world production (as defined in eq. [4]) averaged across all twenty-eight manufacturing industries.

1980s. We note that this latter interpretation is consistent with the tradethickness evidence.

\subsubsection{Production Fragmentation: Evidence from Value-Added and Gross Output}

Our final quantity-based integration measure is the ratio of value added to gross output (VAGO) within industries. With the UNIDO data we can construct this ratio for each industry-year, $\mathrm{VAGO}_{i t}$, again for all 28 threedigit ISIC manufacturing industries from 1970 through 1992. In the full sample, $\mathrm{VAGO}_{i t}$ had a mean value of 0.376 (with a standard deviation of 0.102). In the HO-fragmentation world, with integration $\mathrm{VAGO}_{i t}$ should decline as countries focus on narrower mixes of activities within industries and import other activities as intermediate inputs. To test this we estimate

$$
\mathrm{VAGO}_{i t}=\alpha(\mathrm{ID})_{i}+\beta(\mathrm{TD})_{t}+u_{i t},
$$

where, as before, TD is a full set of time dummies. An important data caveat here is that $\mathrm{VAGO}_{i t}$ can change because of changing reliance on domestic intermediate inputs, not just foreign inputs. We have no data on imported intermediate inputs; our results should be interpreted accordingly.

Table 1.14 reports the parameter estimates on the time dummies from equation (7); it also reports results for equation (7) modified by adding the world-endowment-dispersion control. Again the 1970s and 1980s look different. With or without the control for endowments, the time dummies 
Time-Series Trends in World (Value Added/Gross Output) Dispersion

\begin{tabular}{ccc}
\hline & None & Endowments \\
\hline 1970 & 0.423 & 0.066 \\
1971 & 0.336 & -0.019 \\
1972 & 0.340 & -0.012 \\
1973 & 0.342 & -0.007 \\
1974 & 0.331 & -0.016 \\
1975 & 0.327 & -0.018 \\
1976 & 0.328 & -0.015 \\
1977 & 0.317 & -0.023 \\
1978 & 0.315 & -0.023 \\
1979 & 0.313 & -0.021 \\
1980 & 0.318 & -0.011 \\
1981 & 0.318 & -0.010 \\
1982 & 0.310 & -0.017 \\
1983 & 0.319 & -0.010 \\
1984 & 0.319 & -0.012 \\
1985 & 0.311 & -0.023 \\
1986 & 0.314 & -0.019 \\
1987 & 0.317 & -0.023 \\
1988 & 0.325 & -0.020 \\
1989 & 0.318 & -0.027 \\
1990 & 0.355 & 0.006 \\
1991 & 0.329 & 0.034 \\
1992 & 0.377 & n.a. \\
\hline
\end{tabular}

Source: UNIDO (1995) and Summers and Heston (1997).

Note: Each row reports the coefficient estimate on that year's time dummy variable from regression equation (7), where the dependent variable is the ratio of value added to gross output. Exact definition of control variable is given in the text. All regressions contain 644 observations. n.a. $=$ not available.

in equation (7) generally declined during the 1970s, then plateaued during the 1980s and increased sharply the last few years. Figure 1.5 displays these trends by averaging $\mathrm{VAGO}_{i t}$ across all twenty-eight industries in each year. The fall in the 1970s and subsequent stalling is clear.

\subsubsection{Summary of Quantity Evidence}

Viewed from the HO-fragmentation perspective, our quantity evidence suggests that product markets have integrated since 1970 but at quite different rates over time. There was sizable, steady integration during the 1970s. The 1980s had very little integration overall: Integration actually reversed initially, only to recover this reversal by the end of the decade. We note that these decade differences broadly match the trend in U.S. natural trade barriers shown in figure 1.1. These differences also have a parallel in the recent product-price studies linking rising U.S. wage inequality with Stolper-Samuelson price effects. The consensus of these studies is that during the 1970s the U.S. relative price of unskilled-labor- 


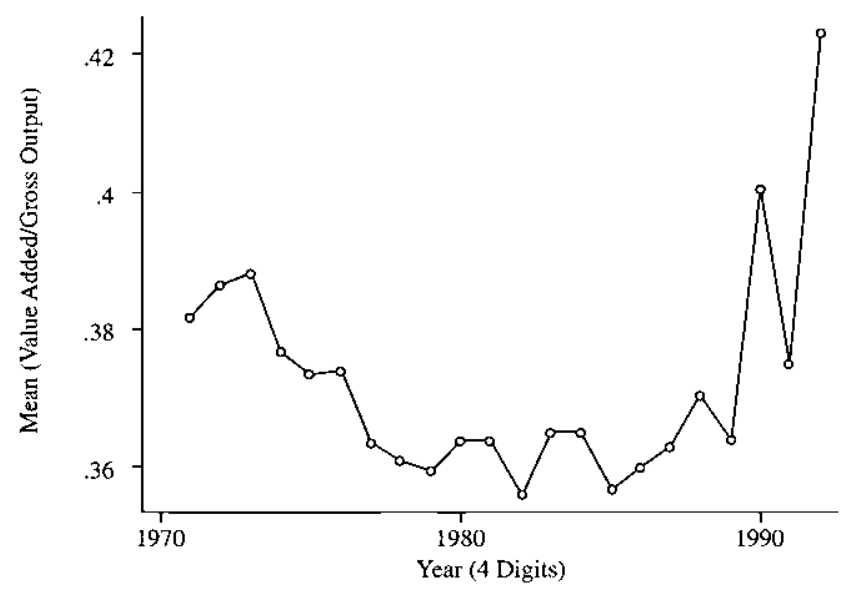

Fig. 1.5 World (value added/gross output): all manufacturing Source: UNIDO (1995).

Note: Each year plots the ratio of value added to gross output averaged across all twentyeight manufacturing industries.

intensive products declined, but that this decline did not continue during the 1980s. These price changes suggest that the U.S. economy liberalized during the 1970s but not in the 1980s - a split in timing that matches our quantity evidence.

In interpreting these integration measures, we reiterate our position that these measures do not link outcomes back to trade barriers. Without these links we cannot rule out the possibility that forces other than declining barriers, such as economic growth, drove the changes in outcomes. In our analysis we have included some first-pass controls for these other forces, such as cross-country dispersion of endowments and per capita income. Our outcomes-based integration measures look quite similar either way, so these measures hopefully relate to the underlying integration process.

\subsection{Conclusion}

In this paper we have presented some new price- and quantity-based measures of product-market integration. Our price measures do not permit very strong conclusions about the changing nature of market integration. Both the absolute and relative price information available does confirm that European countries seem to be moving toward a single market. There is little to suggest convergence toward common prices among Europe and the United States or the United Kingdom, however. We have limited price data on linkages between developed and developing countries. The developing-country evidence is mixed: Some countries seem to 
converge in relative prices but others do not. Our quantity evidence suggests that product markets have integrated since 1970, but at quite different rates over time. There was sizable, steady integration during the 1970s. But the 1980s had much less integration overall: It reversed initially and then recovered.

These new measures we regard as a first step in trying to quantify more accurately the process of product-market integration. We have tried to use data that are readily available to other researchers, to permit further steps in this direction. With refinement, we think measures such as these will help researchers understand the links between integration and domesticeconomy outcomes.

\section{References}

Bhagwati, Jagdish, and Vivek Dehejia. 1994. Free trade and wages of the unskilled: Is Marx striking again? In Trade and wages, ed. J. Bhagwati and M. Kosters, 36-75. Washington, D.C.: American Enterprise Institute.

Feenstra, Robert C. 1996. U.S. imports, 1972-1994: Data and concordances. NBER Working Paper no. 5515. Cambridge, Mass.: National Bureau of Economic Research, March.

. 1998. Integration of trade and the disintegration of production. Journal of Economic Perspectives 12 (fall): 31-50.

Feenstra, Robert C., Robert E. Lipsey, and Harry P. Bowen. 1997. World trade flows, 1970-1992, with production and tariff data. NBER Working Paper no. 5910. Cambridge, Mass.: National Bureau of Economic Research, January.

Harrigan, James. 1993. OECD imports and trade barriers in 1983. Journal of International Economics 35 (1/2): 91-111.

Helpman, Elhanan. 1987. Imperfect competition and international trade: Evidence from fourteen industrial countries. Journal of the Japanese and International Economies 1 (1): 62-81.

Irwin, Douglas A. 1996. The United States in a new global economy? A century's perspective. American Economic Review 86 (May): 41-46.

Kravis, Irving, and Robert E. Lipsey. 1977. Export prices and the transmission of inflation. American Economic Review 67 (February): 155-63.

Krugman, Paul R. 1995. Growing world trade: Causes and consequences. Brookings Papers on Economic Activity, no. 1:327-77.

Leamer, Edward E. 1998. In search of Stolper-Samuelson linkages between international trade and lower wages. In Imports, exports and the American worker, ed. Susan Collins, 141-214. Washington, D.C.: Brookings Institution.

Lipsey, Robert E. 1963. Price and quantity trends in the foreign trade of the United States. Princeton, N.J.: Princeton University Press.

Statistisches Bundesamt. Various issues. Fachserie 7, Reihe 2, Aussenhandel nach Warren und Landern. Weisbaden, Germany.

Summers, Robert, and Alan Heston. 1997. Penn World Tables, Mark 5.6. Available at http://www.nber.org/data.html.

United Nations Industrial Data Organization (UNIDO). 1995. UNIDO database. Available at http://www.unido.org/. 
U.S. Department of Commerce. Various years. U.S. exports: Schedule E. Commodity by country. Washington, D.C.: GPO.

World Bank. 1993. Purchasing power of currencies: Comparing national incomes using ICP data. Washington, D.C.: World Bank.

\section{Comment James Harrigan}

"Everyone knows" that product markets have become more internationally integrated in recent decades: Trade has grown faster than output, trade barriers and transport costs have fallen, and the word "globalization" has become almost as ubiquitous as the word "Lewinsky." Knetter and Slaughter's contribution in this paper is to try to confirm this conventional wisdom, and in the process they show how difficult it is to do so.

Rather than looking directly at the trends in trade and communications costs that are widely thought to be causing globalization, the authors look instead at outcomes. The main advantage of this strategy is pragmatic: Trade flows and international prices are easier to measure than trade and communications costs. ${ }^{1}$ A crucial disadvantage, which the authors acknowledge, is that outcomes may change for reasons unrelated to changes in trade costs. This makes it important to control for the other determinants of changes in trade flows and international prices, but Knetter and Slaughter make only limited efforts in this regard.

\section{Prices}

Knetter and Slaughter have three types of price data: export unit values, the prices of a bad food and a good magazine, and relative internal prices from the International Comparisons Program (ICP).

Turning first to the export unit-value data, they ask, "Has dispersion of prices for the 'same' good decreased over time?" The answer appears to be no. The key problem here is the usual problem with unit values: If the composition of the category changes, then changes in its unit value only partially reflect changes in prices of specific goods. Nevertheless, the failure of unit-value dispersion to fall is weak evidence that barriers to arbitrage are still big enough to matter. This is not to say that resale costs haven't fallen, since a decline in costs from "prohibitive" to "half as big, but still prohibitive" will not show up in the data used here.

The data on Big Macs and The Economist don't suffer from comparability problems, but price differences surely reflect continuing high resale costs. No imaginable decline in transport costs will lead to Big Mac arbi-

James Harrigan is a senior economist at the Federal Reserve Bank of New York and a faculty research fellow of the National Bureau of Economic Research.

1. For some painstaking work on direct measurement of these costs, see Hummels (1999a, 1999b). 
trage, and the timeliness of a weekly magazine makes it unlikely that arbitrage of The Economist will ever be profitable. The authors state that easier tradability of inputs should lead to price convergence in nontraded goods even if resale costs are prohibitive, but this is true only if the traded component of marginal costs is high and demand elasticities are similar across markets. $^{2}$ I conclude that the data on Big Macs and The Economist shed little light on product-market integration.

The ICP data are not ideal, primarily because they are final customer prices and therefore reflect differences in internal taxes and distribution margins across countries. The authors' methodology is also not ideal: Their conclusions depend on the base country, and they weight all goods equally. Nevertheless, some of the results are striking: Relative prices within continental Europe are very similar, and it appears that relative prices are becoming more similar among richer countries generally.

\section{Quantities}

In addition to price data, Knetter and Slaughter look at three types of quantity data: the number of bilateral trade flows, the dispersion of industry output levels, and the value-added share of gross output by industry.

If there are fixed costs to trade, then the number of bilateral trade flows in the world will increase if these costs fall, holding the distribution of output and demand fixed. The authors show that "market thickness" has increased over time, and this inference holds regardless of whether controls for output or demand are included in the analysis. This seems like solid evidence of increased market integration.

The second quantity analysis looks at the dispersion of production across countries using Herfindahl indexes. The motivation of this analysis is unclear, since the authors acknowledge that integration has no particular implications for the dispersion of production. As a tool for analyzing dispersion, a drawback of the Herfindahl index is that its value will change if relative country sizes change, even if the composition of outputs within each country stays constant. Expressing outputs as a share of GDP, and looking at differences in the output mix across countries, would address this shortcoming of the Herfindahl index.

The final data analysis tries to address the "production fragmentation" or "outsourcing" phenomenon by looking at trends in the ratio of value added to gross output: This may fall as fragmentation increases. As the authors recognize, however, fragmentation may increase with no increase in international integration, which means that the analysis sheds little light on the subject of the paper.

2. This is true unless nontraded prices are determined by traded prices in general equilibrium, as will be the case if there is perfect competition in all markets and at least as many traded goods/factors as there are nontraded goods/factors. 


\section{Conclusion}

Of the six data analyses in the paper, two offer the most direct evidence of increased product-market integration: the ICP price data and the "market thickness" quantity data. The paper makes a contribution to a small but growing literature on measuring product-market integration, and the authors deserve credit for their contribution as well as for forthrightly acknowledging the limitations of their analysis.

\section{References}

Hummels, D. 1999a. Toward a geography of trade costs. University of Chicago Graduate School of Business. Mimeograph.

. 1999b. Transportation costs and the growth of world trade. University of Chicago Graduate School of Business. Mimeograph. 